\title{
EXCHANGEABLE CATIONS IN FINNISH SOILS
}

\author{
Ulla MartTila
}

\begin{abstract}
University of Helsinki, Department of Agricultural Chemistry, Pihlajamäki
\end{abstract}
Received January 15, 1965

The exchangeable cations in Finnish soils have not been an object of particularly intensive study. In the papers of Kivinen (10) and Aarnio (1) attention has been paid mainly to the T-, S-, and V-values in Finnish clay soils. Further information has been given by e.g. Keränen (9), Heinonen (4. 5), SAlonen (15) and PuUstJärvi (14).

In the present paper results obtained on a larger material of Finnish soil samples are reported. In addition to the cation exchange capacity and the percentage base saturation also the most common exchangeable cations in the different soil types are determined.

\section{Material and methods}

The material of the present work consists of 100 soil samples collected from various parts of our country. 35 samples are from the plough layer, and 32 samples from the deeper layers of cultivated soils, 14 samples from the surface layer, and 19 samples from the deeper layers of virgin soils. The profile samples of the layer $0-20 \mathrm{~cm}$ are marked by $a, 20-30 \mathrm{~cm}$ by $b$, and $50-60 \mathrm{~cm}$ by $c$, except in the profiles Jo a-f and Hä a-d the layer $0-20 \mathrm{~cm}$ is marked by $a, 50-60 \mathrm{~cm}$ by $b$, $100-110 \mathrm{~cm}$ by $c, 150-160 \mathrm{~cm}$ by $d, 200-210 \mathrm{~cm}$ by $e$, and $250-260 \mathrm{~cm}$ by $f$.

On the basis of the mechanical analyses performed by the areometric procedure of Soveri and Hilpi (18) the mineral soils are grouped to the textural classes used in Finland:

sand and fine sand soils

loam and silt soils

clay soils

$$
\begin{array}{cc}
\varnothing<0,002 \mathrm{~mm} & 0,002-0,02 \mathrm{~mm} \\
<30 \% & >50 \% \\
<30 \% & <50 \% \\
>30 \% &
\end{array}
$$

Thus the material consists of 45 samples of clay soils, 26 samples of loam and silt soils, and 11 samples of sand and fine sand soils. In addition there are 18 samples of organic soils containing more than $8,5 \%$ organic carbon. 
The soil $\mathrm{pH}$ was measured in a 1 to 2,5 suspension in $0.01 \mathrm{M} \mathrm{CaCl}_{2}$ by a Beckman $\mathrm{pH}$ meter with a glass electrode. The content of soil organic carbon was determined by a modified method of WALKLEY (19) using the iodometric titration.

Exchangeable cations were leached from air-dried, ground soil samples with neutral $1 \mathrm{~N}$ ammonium acetate by a modified method of Schollenberger and Simons (17).

A $5 \mathrm{~g}$ sample of organic soil or a $10 \mathrm{~g}$ sample of mineral soil was weighed in a Metson tube. Into these tubes the following layers were packed: 1) about $5 \mathrm{~cm}$ finely torn filter paper 2) $5 \mathrm{~g}$ of washed quartz sand 3) the weighed soil sample mixed with an equal amount of quartz sand 4) $5 \mathrm{~g}$ of quartz sand. Ammonium acetate was added in portions of $50 \mathrm{ml}$, the total amount was $200 \mathrm{ml}$.

The percolation was adjusted so that the period of leaching was 4 to 8 hours. Exchangeable hydrogen was determined by titrating the soil leachates with $0,1 \mathrm{~N} \mathrm{NaOH}$ electrometrically using a glass electrode to the $\mathrm{pH} \mathbf{7 . 0}$ of the original ammonium acetate solution. Exchangeable calcium, potassium and sodium were determined directly from the soil leachates using the Beckman Model DU spectrophotometer with the flame attachment 9200 . In the determinations the following wavelengths were used: Ca $554 \mathrm{~m} \mu$, K $768 \mathrm{~m} \mu$, and Na $589 \mathrm{~m} \mu$.

Magnesium was determined from the filtrates by versene titration after calcium was first precipitated as oxalate $(6)$

$\mathrm{CEC}$ values were calculated as the sum of all exchangeable cations, and the percentage base saturation from the equation $100 \times \frac{\Sigma \text { exchangeable bases }}{\text { CEC }}$

\section{The accuracy of analyses}

All the analyses were performed at least in duplicates. Usually a fairly low degree of accuracy may be obtained in studies of cation exchange in the routine work. Looking for the sources of errors in these determinations the variation in the efficiency of leaching, the heterogenesity of the soil, the disturbing ions in the leachates and the particular measuring errors may be among the most important ones. The ratio of soil to solution was 1 to 20 in the mineral soils, which FIELDES and his co-workers (3) claim to result in a nearly perfect exchange. It was, however, impossible to make the rate of percolation quite equal for all the samples, and that could cause some differences in the determinations. In order to minimize the effect of other cations the standard solutions were compensated for the average amounts of the most common cations.

In the magnesium determinations from the strongly coloured organic soil leachates first organic matter and $\mathrm{NH}_{4}$, and then $\mathrm{P}, \mathrm{Al}, \mathrm{Fe}, \mathrm{Mn}$ were removed (7).

In order to get an idea about the accuracy of the analyses ten parallel leachings were made with two of the soil samples. The means of the results with the confidence limits at the 95 per cent level were the following expressed as me/100 $\mathrm{g}$ of soil.

$\begin{array}{lcccccc} & \mathrm{Ca} & \mathrm{Mg} & \mathrm{K} & \mathrm{Na} & \mathrm{H} & \mathrm{CEC} \\ \text { To/60 } & 38.9 \pm 0.32 & 6.8 \pm 0.23 & 0.86 \pm 0.04 & 0.74 \pm 0.06 & 15.9 \pm 0.28 & 63.3 \pm 0.54 \\ \text { U A a } & 30.1 \pm 0.42 & 7.7 \pm 0.16 & 0.71 \pm 0.03 & 0.26 \pm 0.01 & 5.1 \pm 0.14 & \mathbf{4 3 . 8} \pm 0.52\end{array}$

It seems that in the determinations of calcium, magnesium and hydrogen the accuracy of 0.1 me per $100 \mathrm{~g}$ and in the determinations of potassium and sodium 
the accuracy of 0.01 me per $100 \mathrm{~g}$ could be attained. The results in Table 1 are, however, reported at the customary accuracy of 0.1 me per $100 \mathrm{~g}$ for calcium, magnesium and hydrogen and at the accuracy of 0.01 me per $100 \mathrm{~g}$ for potassium and sodium.

\section{Results}

The results obtained for various soil samples are reported in Table 1 . In addition to the values of cation exchange capacity, percentage base saturation and the amounts of exchangeable calcium, magnesium, potassium, sodium and hydrogen, also the contents of clay and organic carbon, and the $\mathrm{pH}$-values of the soil samples are listed there.

In this material distinct differences exist in the results between and also within the various soil types. The largest variations in the amounts of the exchangeable cations and in the values of the percentage base saturation may be found in the group of clay soils. This seems to be due to the fact that there are samples both of Litorina clays (Vi la-c, Vi 3a-c, Vi 4b-c, Vi 6a-c, V4N, UL a-b, P a-c) and of typical Glacial clays (Jo a-f, UA a-c, Hä c-d, Sa c, Mo b-c). The Glacial clays have been deposited in the sweet water during or immediately after the Glacial period and the Litorina clays are our youngest marine sediments deposited in the salty water of the so-called Litorina Sea.

Table 1. Exchangeable cations of the soil samples.

\begin{tabular}{|c|c|c|c|c|c|c|c|c|c|c|c|}
\hline \multirow[b]{2}{*}{ Sample } & \multirow[b]{2}{*}{ Place } & \multirow[b]{2}{*}{$\begin{array}{c}\text { Clay } \\
\%\end{array}$} & \multirow[b]{2}{*}{$\begin{array}{c}\text { Org. C } \\
\%\end{array}$} & \multirow[b]{2}{*}{$\mathrm{pH}$} & \multicolumn{6}{|c|}{ Exchangeable cations me $/ 100 \mathrm{~g}$} & \multirow[b]{2}{*}{ BS $\%$} \\
\hline & & & & & $\mathrm{Ca} * *$ & $\mathrm{Mg}^{* *}$ & $\mathrm{~K}^{*}$ & $\mathrm{Na} *$ & $\mathrm{H}^{*}$ & Total. & \\
\hline
\end{tabular}

\begin{tabular}{|c|c|c|c|c|c|c|c|c|c|c|c|}
\hline $\mathrm{UA}$ a & Uskela & 56 & 3.2 & 6.0 & 29.9 & 7.8 & 0.71 & 0.26 & 5.1 & 43.8 & 88 \\
\hline Vi 3a & Viiki & 47 & 4.6 & 4.6 & 12.7 & 1.0 & 1.38 & 0.10 & 23.2 & 38.4 & 40 \\
\hline U L a & Uskela & 65 & 3.4 & 4.7 & 13.7 & 5.3 & 0.77 & 0.18 & 15.5 & 35.5 & 56 \\
\hline 1509 & Pukkila & 58 & 5.5 & 5.0 & 12.3 & 6.8 & 0.38 & 0.24 & 15.3 & 35.0 & 56 \\
\hline V $4 \mathrm{~N}$ & Viiki & 47 & 5.4 & 4.6 & 12.6 & 1.1 & 1.2 & 0.14 & 17.9 & 30.0 & 46 \\
\hline Vi la & Viiki & 46 & 2.9 & 3.5 & 2.4 & 2.0 & 0.60 & 0.36 & 26.7 & 32.1 & 17 \\
\hline $\mathrm{V} 2 \mathrm{~N}$ & Viiki & 40 & 4.6 & 4.7 & 15.6 & 1.1 & 0.89 & 0.12 & 12.2 & 29.9 & 59 \\
\hline $\mathrm{P}$ a & Porvoo & 35 & 5.1 & 5.1 & 14.0 & 1.4 & 0.77 & 0.35 & 9.1 & 25.6 & 65 \\
\hline Vi $2 a$ & Viiki & 45 & 1.0 & 4.7 & 8.3 & 3.4 & 0.53 & 0.20 & 8.8 & 21.2 & 59 \\
\hline Vi 6a & Viiki & 29 & 2.9 & 4.2 & 4.7 & 1.0 & 0.84 & 0.17 & 13.1 & 18.9 & 34 \\
\hline \multicolumn{12}{|c|}{ Clay soils, deeper layers } \\
\hline Sa c & Savio & 83 & 0.2 & 6.5 & 21.2 & 15.8 & 0.82 & 0.64 & 3.6 & 42.1 & 91 \\
\hline Vi lc & Viiki & 51 & 2.2 & 3.3 & 2.6 & 3.6 & 0.53 & 0.95 & 28.0 & 35.6 & 21 \\
\hline Jo b & Jokela & 80 & 0.2 & 5.8 & 14.4 & 15.2 & 0.96 & 0.77 & 3.9 & 35.2 & 89 \\
\hline U A c & Uskela & 70 & 0.6 & 5.7 & 18.0 & 11.7 & 0.83 & 0.46 & 4.0 & 35.0 & 88 \\
\hline $\mathrm{U}$ A b & Uskela & 66 & 1.6 & 5.8 & 20.2 & 8.5 & 0.38 & 0.30 & 5.2 & 34.6 & 85 \\
\hline
\end{tabular}

\begin{tabular}{|c|c|c|c|c|c|c|c|c|c|c|c|}
\hline $\mathrm{UA}$ a & Uskela & 56 & 3.2 & 6.0 & 29.9 & 7.8 & 0.71 & 0.26 & 5.1 & 43.8 & 88 \\
\hline Vi 3a & Viiki & 47 & 4.6 & 4.6 & 12.7 & 1.0 & 1.38 & 0.10 & 23.2 & 38.4 & 40 \\
\hline U L a & Uskela & 65 & 3.4 & 4.7 & 13.7 & 5.3 & 0.77 & 0.18 & 15.5 & 35.5 & 56 \\
\hline 1509 & Pukkila & 58 & 5.5 & 5.0 & 12.3 & 6.8 & 0.38 & 0.24 & 15.3 & 35.0 & 56 \\
\hline V $4 \mathrm{~N}$ & Viiki & 47 & 5.4 & 4.6 & 12.6 & 1.1 & 1.2 & 0.14 & 17.9 & 30.0 & 46 \\
\hline Vi la & Viiki & 46 & 2.9 & 3.5 & 2.4 & 2.0 & 0.60 & 0.36 & 26.7 & 32.1 & 17 \\
\hline $\mathrm{V} 2 \mathrm{~N}$ & Viiki & 40 & 4.6 & 4.7 & 15.6 & 1.1 & 0.89 & 0.12 & 12.2 & 29.9 & 59 \\
\hline $\mathrm{P}$ a & Porvoo & 35 & 5.1 & 5.1 & 14.0 & 1.4 & 0.77 & 0.35 & 9.1 & 25.6 & 65 \\
\hline Vi $2 a$ & Viiki & 45 & 1.0 & 4.7 & 8.3 & 3.4 & 0.53 & 0.20 & 8.8 & 21.2 & 59 \\
\hline Vi 6a & Viiki & 29 & 2.9 & 4.2 & 4.7 & 1.0 & 0.84 & 0.17 & 13.1 & 18.9 & 34 \\
\hline \multicolumn{12}{|c|}{ Clay soils, deeper layers } \\
\hline Sa c & Savio & 83 & 0.2 & 6.5 & 21.2 & 15.8 & 0.82 & 0.64 & 3.6 & 42.1 & 91 \\
\hline Vi lc & Viiki & 51 & 2.2 & 3.3 & 2.6 & 3.6 & 0.53 & 0.95 & 28.0 & 35.6 & 21 \\
\hline Jo b & Jokela & 80 & 0.2 & 5.8 & 14.4 & 15.2 & 0.96 & 0.77 & 3.9 & 35.2 & 89 \\
\hline U A c & Uskela & 70 & 0.6 & 5.7 & 18.0 & 11.7 & 0.83 & 0.46 & 4.0 & 35.0 & 88 \\
\hline $\mathrm{U}$ A b & Uskela & 66 & 1.6 & 5.8 & 20.2 & 8.5 & 0.38 & 0.30 & 5.2 & 34.6 & 85 \\
\hline
\end{tabular}

Clay soils, surface layers 
Exchangeable cations me/100 g

\begin{tabular}{|c|c|c|c|c|c|c|c|c|c|c|c|}
\hline Sample & Place & $\begin{array}{c}\text { Clay } \\
\%\end{array}$ & $\begin{array}{c}\text { Org. C } \\
\% \\
\end{array}$ & $\mathrm{pH}$ & $\mathrm{Ca} * *$ & $\mathrm{Mg} * *$ & $\mathrm{~K}^{*}$ & $\mathrm{Na}^{*}$ & $\mathrm{H}^{*}$ & Total. & BS $\%$ \\
\hline Jo d & Jokela & 82 & 0.1 & 6.2 & 14.2 & 15.0 & 0.97 & 0.45 & 3.4 & 34.0 & 90 \\
\hline Jo c & Jokela & 80 & 0.1 & 6.1 & 14.0 & 15.0 & 0.97 & 0.43 & 3.5 & 33.9 & 90 \\
\hline Jo e & Jokela & 82 & 0.1 & 6.0 & 14.2 & 15.1 & 0.95 & 0.42 & 2.9 & 33.6 & 91 \\
\hline 1510 & Pukkila & 64 & 0.7 & 6.0 & 14.1 & 12.9 & 0.41 & 0.58 & 5.6 & 33.6 & 83 \\
\hline 1514 & Mäntsälä & 57 & 0.5 & 5.2 & 16.2 & 8.3 & 0.50 & 0.54 & 5.6 & 31.1 & 82 \\
\hline Vi 3c & Viiki & 72 & 1.6 & 3.7 & 1.3 & 1.2 & 0.80 & 0.14 & 27.2 & 30.6 & 11 \\
\hline Vi lb & Viiki & 42 & 2.9 & 3.6 & 1.6 & 1.8 & 0.51 & 0.37 & 25.7 & 30.0 & 14 \\
\hline U L c & Uskela & 57 & 0.5 & 5.7 & 12.2 & 12.3 & 0.62 & 0.31 & 4.6 & 30.0 & 85 \\
\hline $\mathrm{Pc}$ & Porvoo & 63 & 1.2 & 4.1 & 12.7 & 1.4 & 0.84 & 0.33 & 14.5 & 29.8 & 51 \\
\hline $\mathrm{Vi} 2 \mathrm{c}$ & Viiki & 89 & 0.4 & 5.7 & 12.2 & 10.5 & 0.92 & 0.57 & 4.9 & 29.1 & 83 \\
\hline Jo a & Jokela & 82 & 0.5 & 5.6 & 14.5 & 15.2 & 1.07 & 1.20 & 5.6 & 37.6 & 85 \\
\hline 1512 & Mäntsälä & 48 & 0.6 & 5.9 & 12.7 & 10.0 & 0.36 & 0.34 & 4.4 & 27.8 & 84 \\
\hline Vi 3b & Viiki & 54 & 2.1 & 4.0 & 2.0 & 0.96 & 0.75 & 0.08 & 23.2 & 27.0 & 14 \\
\hline Hy 2c & Hyvinkää & 50 & 0.3 & 6.4 & 13.9 & 9.4 & 0.32 & 0.38 & 2.6 & 26.6 & 90 \\
\hline Vi 2b & Viiki & 74 & 0.5 & 5.2 & 10.4 & 7.8 & 0.69 & 0.42 & 6.6 & 25.9 & 74 \\
\hline Hä d & Hämeenlinna & 68 & 0.3 & 6.3 & 11.9 & 11.0 & 0.44 & 0.34 & 2.2 & 25.9 & 92 \\
\hline Hä c & Hämeenlinna & 64 & 0.5 & 6.4 & 11.6 & 10.4 & 0.47 & 0.40 & 2.2 & 25.1 & 91 \\
\hline U L b & Uskela & 68 & 0.9 & 4.6 & 8.1 & 5.9 & 0.31 & 0.23 & 9.8 & 24.3 & 60 \\
\hline Jo f & Jokela & 62 & 0.1 & 6.3 & 12.4 & 8.2 & 0.69 & 0.30 & 2.5 & 24.1 & 90 \\
\hline Vi $6 \mathrm{~b}$ & Viiki & 42 & 2.3 & 3.8 & 4.2 & 1.3 & 0.50 & 0.17 & 17.6 & 23.8 & 26 \\
\hline $\mathrm{Vi} 4 \mathrm{c}$ & Viiki & 46 & 0.4 & 4.0 & 4.3 & 3.5 & 0.55 & 0.21 & 13.9 & 22.4 & 38 \\
\hline $\mathrm{P} \mathrm{c}$ & Porvoo & 30 & 5.3 & 5.2 & 12.5 & 1.1 & 0.54 & 0.22 & 8.5 & 22.9 & 63 \\
\hline Vi $6 \mathrm{c}$ & Viiki & 55 & 2.0 & 4.0 & 4.7 & 1.6 & 0.79 & 0.42 & 14.8 & 22.3 & 33 \\
\hline $\mathrm{Hy} 2 \mathrm{~b}$ & Hyvinkää & 35 & 0.5 & 5.9 & 11.0 & 5.9 & 0.24 & 0.19 & 4.0 & 21.3 & 81 \\
\hline Ha c & Hausjärvi & 43 & 0.1 & 5.5 & 8.1 & 8.0 & 0.34 & 0.39 & 4.1 & 20.9 & 80 \\
\hline $\mathrm{Ha} \mathrm{b}$ & Hausjärvi & 42 & 0.2 & 5.3 & 8.3 & 7.7 & 0.29 & 0.37 & 4.3 & 20.9 & 80 \\
\hline Vi 4b & Viiki & 38 & 1.9 & 3.9 & 2.7 & 1.1 & 0.26 & 0.15 & 16.1 & 20.3 & 21 \\
\hline Mo c & Mouhijärvi & 48 & 0.5 & 5.8 & 9.9 & 7.3 & 0.35 & 0.33 & 2.4 & 02.3 & 88 \\
\hline Mo b & Mouhijärvi & 32 & 0.5 & 5.5 & 8.8 & 5.7 & 0.29 & 0.22 & 4.4 & 19.4 & 77 \\
\hline M c & Muurla & 33 & 0.0 & 5.1 & 7.3 & 6.6 & 0.23 & 0.29 & 2.9 & 17.3 & 83 \\
\hline
\end{tabular}

Loam and silt soils, surface layers

\begin{tabular}{|c|c|c|c|c|c|c|c|c|c|c|}
\hline Hy $2 \mathrm{a}$ & Hyvinkää & 25 & 2.7 & 5.3 & 13.4 & 2.8 & 0.24 & 0.12 & 8.9 & 25.5 \\
\hline HP 2a & Laukaa & 16 & 2.2 & 5.5 & 15.4 & 2.0 & 0.24 & 0.13 & 6.4 & 24.2 \\
\hline K 101 & Laukaa & 22 & 3.5 & 5.2 & 14.4 & 1.7 & 0.36 & 0.11 & 7.5 & 24.1 \\
\hline Vi $4 a$ & Viiki & 24 & 5.0 & 4.3 & 6.0 & 1.5 & 0.26 & 0.11 & 7.5 & 24.1 \\
\hline HP la & Laukaa & 28 & 2.5 & 5.4 & 14.6 & 1.9 & 0.12 & 0.12 & 5.5 & 22.2 \\
\hline $\mathrm{HP} / \mathrm{N}$ & Laukaa & 25 & 2.7 & 5.6 & 13.4 & 1.9 & 0.11 & 0.26 & 5.6 & 21.3 \\
\hline K 1 & Laukaa & 21 & 2.5 & 5.4 & 13.9 & 1.9 & 0.13 & 0.12 & 4.5 & 20.6 \\
\hline K 104 & Laukaa & 18 & 3.7 & 4.6 & 8.0 & 0.8 & 0.17 & 0.12 & 10.6 & 19.7 \\
\hline $\mathrm{M}$ a & Muurla & 24 & 2.4 & 5.3 & 8.4 & 1.6 & 0.57 & 0.24 & 7.5 & 18.3 \\
\hline K 5 & Laukaa & 18 & 2.2 & 5.3 & 11.6 & 1.3 & 0.17 & 0.10 & 4.0 & 17.2 \\
\hline Mo a & Mouhijärvi & 22 & 1.5 & 5.5 & 8.0 & 2.6 & 0.19 & 0.13 & 5.6 & 10.9 \\
\hline Hä a & Hämeenlinna & 26 & 1.1 & 513 & 7.3 & 2.8 & 0.32 & 0.17 & 5.0 & 15.6 \\
\hline $\mathrm{H} \mathrm{a}$ & Hausjärvi & 17 & 1.2 & 4.6 & 1.5 & 0.7 & 0.31 & 1.8 & 11.1 & 15.3 \\
\hline K 2 & Laukaa & 10 & 2.2 & 5.3 & 8.6 & 0.9 & 0.26 & 0.13 & 4.7 & 14.6 \\
\hline Ka a & Kauhajoki & 22 & 0.7 & 4.7 & 5.0 & 3.8 & 0.20 & 0.19 & 5.2 & 14.4 \\
\hline To $9 \mathrm{a}$ & Tohmajärvi & 16 & 1.4 & 4.7 & 2.8 & 1.3 & 0.18 & 0.10 & 6.0 & 10.4 \\
\hline
\end{tabular}




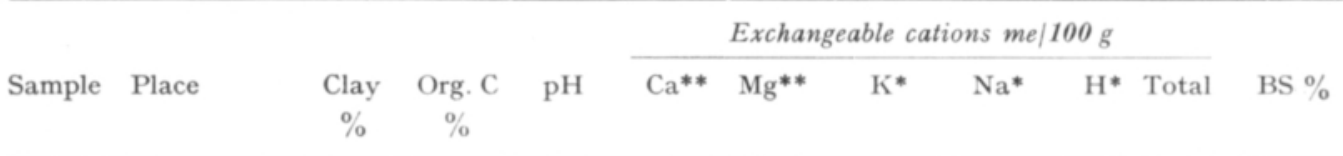

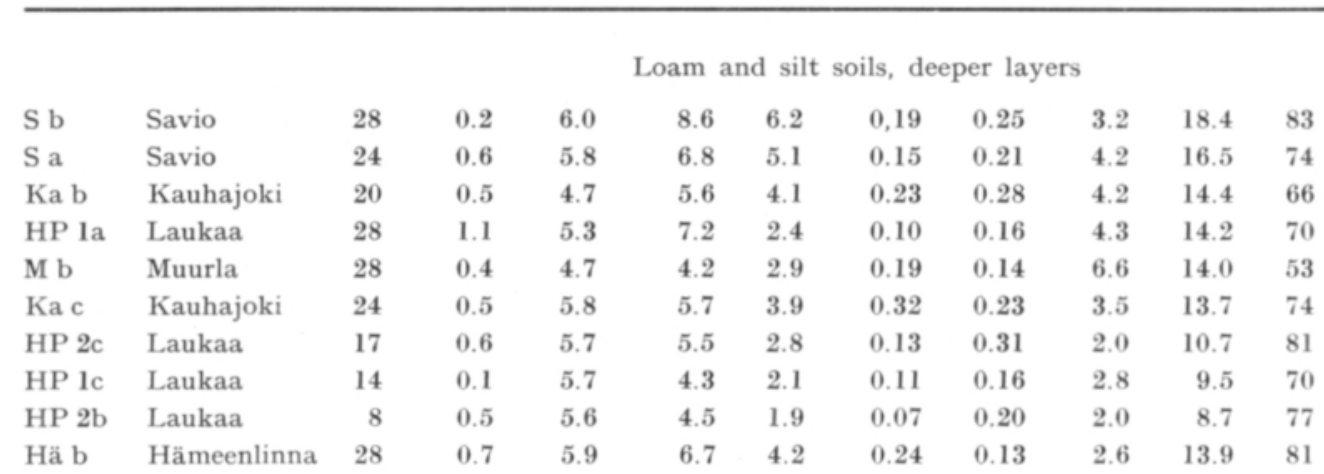

Sand and fine sand soils, surface layers

$\begin{array}{llrrrrrrrrrr}\text { To 7a } & \text { Tohmajärvi } & 6 & 4.8 & 5.7 & 18.6 & 0.6 & 0.41 & 0.15 & 5.6 & 25.4 & 78 \\ \text { To 3a } & \text { Tohmajärvi } & 15 & 4.7 & 5.0 & 7.9 & 0.7 & 0.56 & 0.10 & 15.3 & 24.6 & 38 \\ \text { To 6a } & \text { Tohmajärvi } & 8 & 4.7 & 6.2 & 15.4 & 0.5 & 0.62 & 0.14 & 4.9 & 21.6 & 77 \\ \text { To 2a } & \text { Tohmajärvi } & 6 & 3.6 & 5.1 & 6.5 & 0.6 & 0.45 & 0.09 & 9.3 & 16.9 & 45 \\ \text { To 4a } & \text { Tohmajärvi } & 22 & 2.4 & 5.3 & 7.1 & 1.0 & 0.36 & 0.10 & 6.2 & 14.8 & 58 \\ \text { C 1 } & \text { Laukaa } & 8 & 1.9 & 5.0 & 5.3 & 0.9 & 0.12 & 0.10 & 6.0 & 12.4 & 52 \\ \text { C 2 } & \text { Laukaa } & 0 & 2.9 & 5.2 & 5.5 & 0.8 & 0.09 & 0.12 & 5.2 & 11.7 & 55 \\ \text { To 8a } & \text { Tohmajärvi } & 4 & 2.0 & 5.4 & 4.8 & 0.2 & 0.34 & 0.07 & 4.7 & 10.1 & 53 \\ \text { Ks a } & \text { Kannus } & 6 & 1.0 & 5.3 & 2.5 & 0.9 & 0.18 & 0.36 & 3.2 & 7.1 & 56\end{array}$

Sand and fine sand soils, deeper layers

$\begin{array}{llllllllllll}\text { Ks } & \text { Kannus } & 9 & 0.1 & 5.4 & 2.8 & 1.6 & 0.13 & 0.07 & 2.6 & 7.2 & 64 \\ \text { Kl } & \text { Kannus } & 6 & 0.1 & 5.4 & 2.5 & 1.5 & 0.09 & 0.09 & 2.9 & 7.1 & 68\end{array}$

$\begin{array}{llrrrrrrrrr}\text { RT } & \text { Hyvinkää } & 49.9 & 3.0 & 13.4 & 2.6 & 0.27 & 0.24 & 109.0 & 125.5 & 13 \\ 1515 & \text { Mäntsälä } & 41.7 & 3.9 & 20.8 & 5.8 & 0.38 & 0.33 & 96.7 & 124.0 & 22 \\ \text { A 44 } & & 49.5 & 3.6 & 7.1 & 0.8 & 0.12 & 0.10 & 108.2 & 116.3 & 7 \\ \text { Let P } & \text { Leteensuo } & 33.5 & 4.0 & 36.5 & 3.1 & 0.35 & 0.50 & 75.9 & 116.4 & 35 \\ \text { A 3 } & \text { Helsinki } & 46.8 & 3.5 & 15.9 & 0.9 & 0.19 & 0.43 & 95.2 & 112.6 & 15 \\ \text { A 43 } & & 46.7 & 3.6 & 12.3 & 0.5 & 0.10 & 0.18 & 96.4 & 109.5 & 12 \\ 61070 & \text { Kiikoinen } & 22.5 & 4.6 & 34.0 & 2.2 & 0.31 & 0.20 & 45.0 & 81.7 & 45 \\ 1539 & \text { Askola } & 24.6 & 4.5 & 16.1 & 3.0 & 0.31 & 0.17 & 52.9 & 72.5 & 27\end{array}$




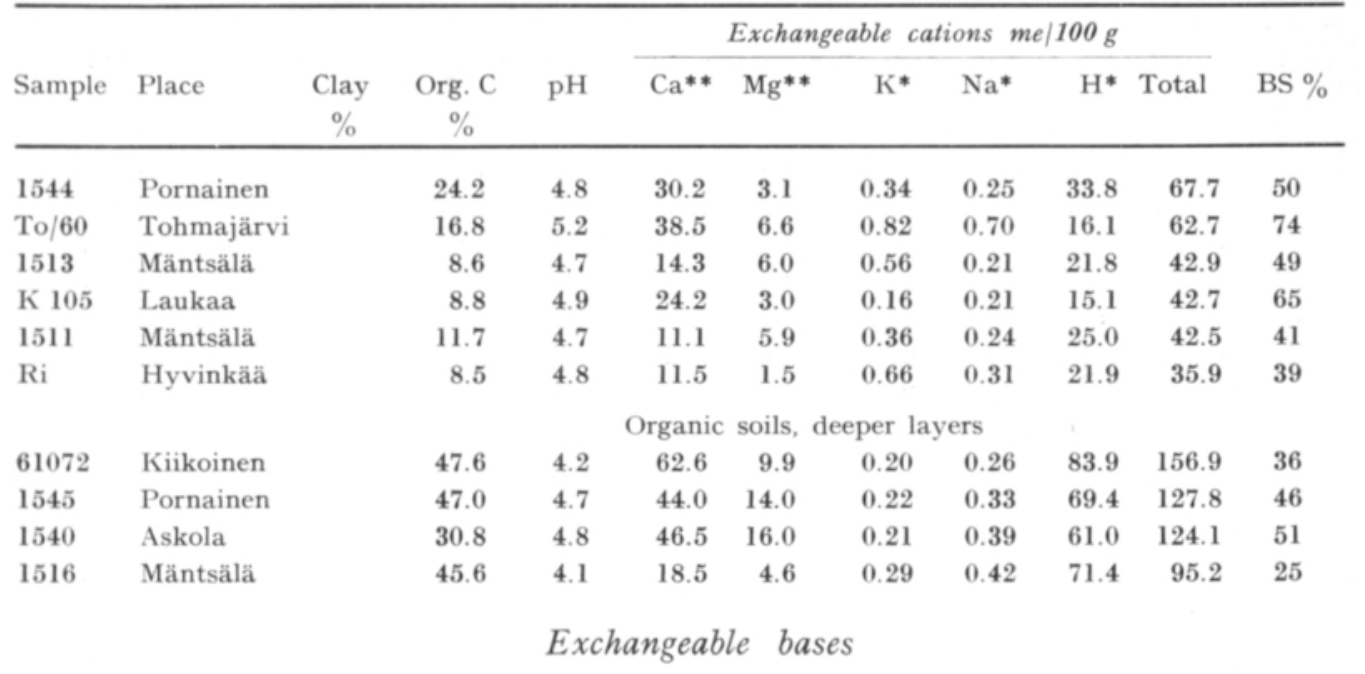

In order to get a better survey of the data in Table 1 the means for the cation contents in the different soil types were computed, expressed both as me/100 $\mathrm{g}$ soil and as a percentage of the total amount of exchangeable cations.

First the exchangeable calcium is studied. In addition to the means with their confidence limits at 95 per cent level also the minimum and maximum values are reported. In the parenthesis the number of samples is given.

\begin{tabular}{|c|c|c|c|c|c|}
\hline \multirow{2}{*}{ non-Litorina clay } & & \multicolumn{2}{|c|}{$\begin{array}{l}\text { Ca me per } 100 \mathrm{~g} \\
\text { mean }\end{array}$} & \multicolumn{2}{|c|}{$\mathrm{Ca} \%$} \\
\hline & & & & & \\
\hline surface & ( 4) & $16.5 \pm 12.7$ & $8.3-29.8$ & $49 \pm 21$ & $35-68$ \\
\hline deeper layers & $(24)$ & $13.0 \pm 1.5$ & $7.3-21.2$ & $45 \pm 0.2$ & $38-58$ \\
\hline Litorina clays & & & & & \\
\hline surface & $(6)$ & $10.0 \pm 5.1$ & $2.4-14.0$ & $33 \pm 16$ & $7-55$ \\
\hline deeper layers & (11) & $5.1 \pm 2.8$ & $1.3-12.7$ & $21 \pm 11$ & $4-55$ \\
\hline loam and silt soil & & & & & \\
\hline surface & (16) & $9.5 \pm 2.4$ & $2.3-15.4$ & $49 \pm 9$ & $10-68$ \\
\hline deeper layers & $(10)$ & $5.9 \pm 1.0$ & $4.2-8.6$ & $45 \pm 5$ & $30-52$ \\
\hline $\begin{array}{l}\text { sand and fine sat } \\
\text { surface } \\
\text { organic soils }\end{array}$ & ( 9$)$ & $8.2 \pm 4.0$ & $2.5-18.6$ & $48 \pm 11$ & $32-73$ \\
\hline surface & (14) & $20.4 \pm 5.9$ & $7.1-38.5$ & $30 \pm 10$ & $6-61$ \\
\hline deeper layers & $(4)$ & $42.9 \pm 25.3$ & $18.5-62.6$ & $33 \pm 13$ & $19-40$ \\
\hline
\end{tabular}

According to these mean values the lowest calcium content seems to be found in the deeper layers of the Litorina clays and of the loam and silt soils, the relative amount of calcium on the other hand appears to be distinctly lower in the organic soils and in the Litorina clays than in the other soil groups. That may be partly attributed to the fact that also the percentage of exchangeable hydrogen is very high in these soil types. The distinct difference between the calcium content of the Glacial clays and the Litorina clays has also previously been observed (2).

The mean quantities of exchangeable magnesium extracted by the present method were the following: 


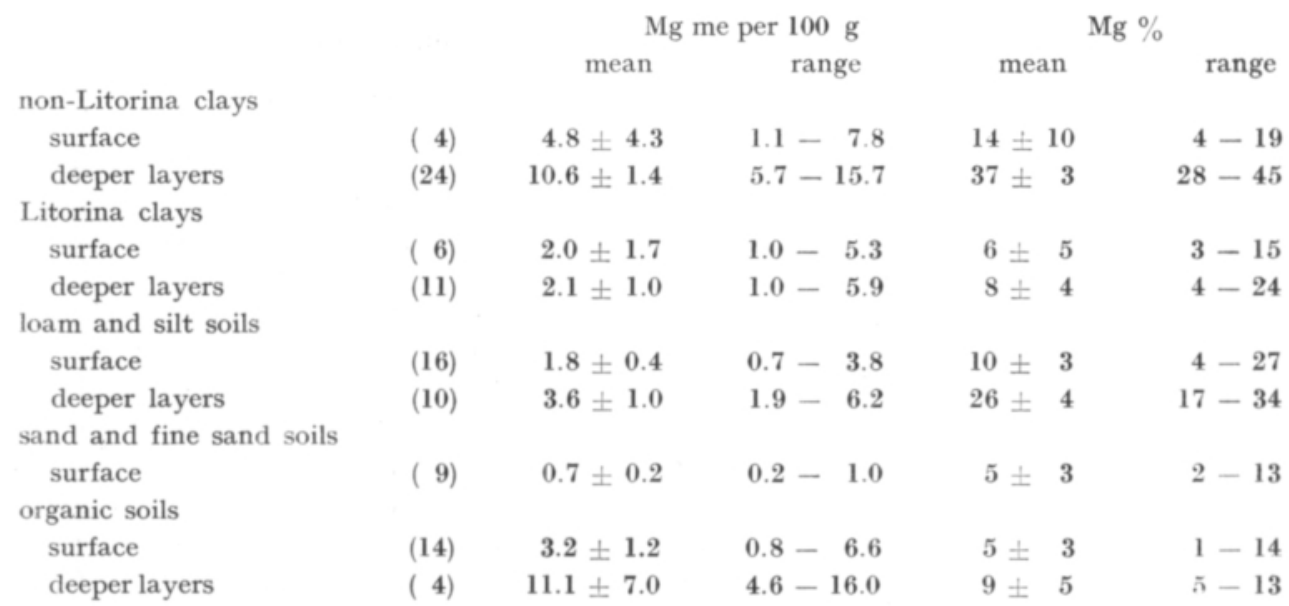

These mean values show very clearly that the highest magnesium content seems to be found in the clay soils except in the Litorina clays, some of which contain really low amounts of magnesium. Loam and silt soils are also fairly rich in magnesium, which is perhaps partly due to the fact that to this group belong soils with a relatively high clay content. Sand and fine sand soils contain quite a low absolute amount of magnesium. Especially high is the magnesium content in the Glacial clay sample of Jokela. Its magnesium content, 40,5 to 45,0 per cent of CEC, which is higher than that of any other exchangeable cation, may be explained by the presence in the parent material of biotite rich in magnesium.

In most groups appreciably lower mean values were found for the contents of exchangeable potassium.

\begin{tabular}{|c|c|c|c|c|c|}
\hline & & \multicolumn{2}{|c|}{$\mathrm{K}$ me per $100 \mathrm{~g}$} & \multicolumn{2}{|c|}{ K \% } \\
\hline & & mean & range & mean & range \\
\hline \multicolumn{6}{|l|}{ non-Litorina clays } \\
\hline surface & ( 4$)$ & $0.63 \pm 0.31$ & $0.38-0.89$ & $2.1 \pm 1.2$ & $1.1-3.0$ \\
\hline deeper layers & $(24)$ & $0.59 \pm 0,12$ & $0.23-1.07$ & $2.0 \pm 0.3$ & $0.9-3.2$ \\
\hline \multicolumn{6}{|l|}{ Litorina soils } \\
\hline surface & ( 6$)$ & $0.92 \pm 0.30$ & $0.6-1.0$ & $3.1 \pm 0.9$ & $1.9-4.2$ \\
\hline deeper layers & (11) & $0,58 \pm 0,13$ & $0.26-0.80$ & $2.2 \pm 0.5$ & $1.2-3.5$ \\
\hline \multicolumn{6}{|c|}{ loam and silt soils } \\
\hline surface & (16) & $0.18 \pm 0.06$ & $0.11-0.57$ & $1.3 \pm 0.4$ & $0.5-3.1$ \\
\hline deeper layers & $(10)$ & $0.17 \pm 0.05$ & $0.07-0.32$ & $1.3 \pm 0.3$ & $0.7-2.3$ \\
\hline sand and fine sa & & & & & \\
\hline surface & ( 9$)$ & $0.35 \pm 0.13$ & $0.09-0.62$ & $2.2 \pm 0.6$ & $0.7-3.3$ \\
\hline \multicolumn{6}{|l|}{ organic soils } \\
\hline surface & (14) & $0.35 \pm 0.12$ & $0.10-0.82$ & $0.6 \pm 0.3$ & $0.1-1.8$ \\
\hline deeper layers & (4) & $0.23 \pm 0.06$ & $0.20-0.29$ & $0.2 \pm 0.17$ & $0.1-0.3$ \\
\hline
\end{tabular}

The loam and silt soils seem to have, on the average, the lowest potassium content, and the relatively lowest amount of potassium appears to be found in the organic soils. The studied Litorina clays, on the contrary, contain large amounts of potassium as compared with the other soils. 
Absolutely and relatively high K-content of the fine sand samples of Tohmajärvi may be mainly due to the parent material rich in illite. The mean values and the variation limits of sodium were of the same order as those of potassium, and in all soil types mostly far lower than the calcium and magnesium contents.

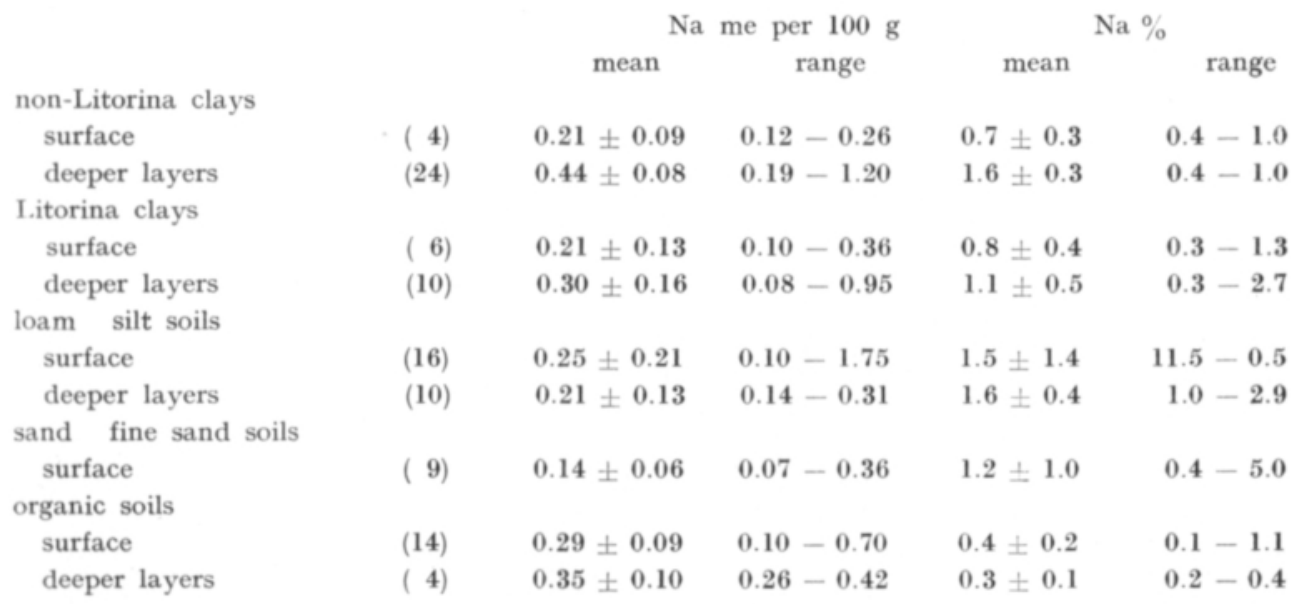

The lowest absolute amount of sodium is to be found in the sand and fine sand soils. Relatively, the organic soils have quite a low and the loam and silt soils quite a high content of sodium.

Cation exchange capacity, percentage base saturation and exchangeable hydrogen

It is well-known that clay particles and humus matter are those soil colloidal constituents, which are primarily responsible for the magnitude of the exchange capacity. Heinonen (5) has studied statistically the exchange capacity of these colloids. According to his results as much as $94 \%$ of the variation in the CEC-values might be explained by the amounts of humus and clay $(<1 \mu)$ colloids.

Also in the present paper the relation between the CEC-values and the contents of clay and organic carbon was studied in mineral soils. The clay percentage used in these calculations represented the amount of clay particles $<2 \mu$. The following regression equation was obtained:

$\mathrm{Y}=4,95^{* * * *} \mathrm{X}_{1}+0,20^{* * * *} \mathrm{X}_{2}+6,70$, in which $\mathrm{Y}$ means the CEC value as me per $100 \mathrm{~g}$ of soil, $\mathrm{X}_{1}$ the per cent of organic carbon, and $\mathrm{X}_{2}$ the per cent of clay. The partial regression coefficient was found to be very significant. Multiple correlation coefficient was $\mathrm{R}=0,84$, and the contents of clay and organic carbon explained 70 per cent of the variation of the exchange capacity of these mineral soils.

The mean values and the ranges of the cation exchange capacity and the percentage base saturation in the different soil types of this material are: 


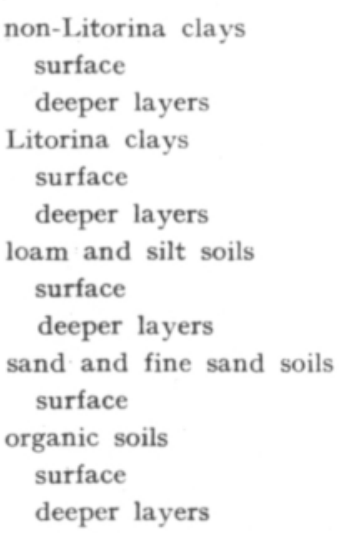

$\begin{array}{rrrrr}\text { ( } 4) & 32.5 \pm 14.2 & 21.2-43.9 & 66 \pm 36 & 56-88 \\ (14) & 28.6 \pm 28 & 17.3-42.1 & 86 \pm 2 & 77-92 \\ & & & & \\ (6) & 30.7 \pm 6.8 & 19.8-38.3 & 43 \pm 17 & 17-65 \\ (11) & 26.3 \pm 3.1 & 20.3-35.6 & 32 \pm 13 & 11-63 \\ & & & & \\ (16) & 19.0 \pm 2.3 & 10.4-25.4 & 62 \pm 8 & 28-77 \\ (10) & 13.4 \pm 2.1 & 8.6-18.4 & 73 \pm 6 & 53-83 \\ & & & & \\ (9) & 16.1 \pm 4.9 & 7.1-25.4 & 57 \pm 10 & 38-78 \\ \text { (14) } & 82.4 \pm 19.4 & 35.9-125.5 & 35 \pm 12 & 7-74 \\ (4) & 126.0 \pm 35.0 & 95.2-156.8 & 42 \pm 16 & 25-51\end{array}$

The highest CEC values per weight are, of course, obtained in the organic soils and clay soils, because these soil types have the greatest amount of colloids. In the proper peat soils CEC values vary from $67.9-156.8 \mathrm{me} / 100 \mathrm{~g}$. The averagely rather low content of exchangeable bases is partly due to the fact that among the studied soils there were several unfertilized virgin peats (samples RT, A3, A43, A44).

In the different clay soils $\mathrm{CEC}$ and $\mathrm{BS} \%$ vary characteristically. The average BS-value of the typical Glacial clays is $85 \%$ ranging from 77 to $92 \%$, and in the Litorina clays BS \% is, on the average, $36 \%$ ranging from 11 to $65 \%$. Appreciably lower CEC values may be found in the loam and silt soils and in the sand and fine sand soils. Generally, these soils seem to be somewhat richer in exchangeable bases than in exchangeable hydrogen, so that the BS values are in several cases over $50 \%$, reaching even to $83 \%$, and on an average they are $64 \%$.

In this connection no attempt is made to specify various factors resulting in consumption of alkali in the determination of the so-called exchangeable hydrogen. Thus the following mean values also contain other factors behaving like hydrogen.

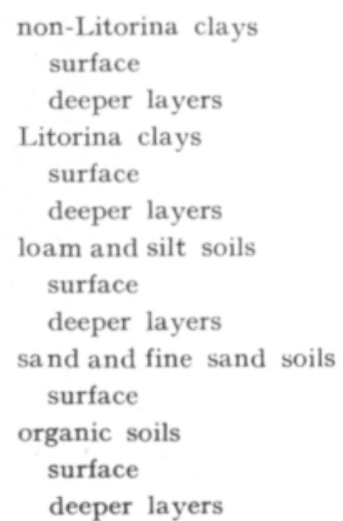

\section{$\mathrm{H}$ me per $100 \mathrm{~g}$ mean}

$\begin{aligned} 10.3 & \pm 6.1 \\ 4.0 & \pm 0.5 \\ 17.6 & \pm 6.4 \\ 18.1 & \pm 4.6 \\ 7.1 & \pm 1.0 \\ 3.6 & \pm 1.0 \\ 6.7 & \pm 2.7 \\ 58.1 & \pm 21.1 \\ 71.4 & \pm 13.1\end{aligned}$

$5.1-17.3$
$2.2-6.6$
$9.1-26.7$
$9.8-27.9$
$4.0-16.1$
$2.0-6.6$
$3.2-15.3$
$15.1-109.0$
$61.0-83.9$

$\mathrm{H} \%$ mean range

$$
\begin{array}{r}
12-44 \\
8-26 \\
36-83 \\
37-89 \\
22-72 \\
18-47 \\
22-62 \\
\\
26-93 \\
49-75
\end{array}
$$


According to these means the highest amounts of exchangeable hydrogen, both absolutely and relatively, are to be found in the groups of the Litorina clays and the organic soils. The loam and silt soils and the sand and fine sand soils also contain relatively high amounts of exchangeable hydrogen, especially in the surface layers. The lowest percentage of hydrogen is obtained in the group of the non-Litorina clays.

\section{Exchangeable cations in various layers of the soil.}

The distribution of exchangeable cations in various layers of soil profiles primarily depends on the intensity with which the cations are adsorbed or fixed by the soil, on the leaching conditions, on the amounts of cations carried from the neighbourhood, and also on the utilization of nutrient cations by the surface vegetation. It is noticed when examining the different depths of the soil profiles within this material that the cation exchange capacity tends to decrease in the deeper layers, where the influence of humus no more exists. Because of the leaching of nutrient cations from the upper layers the percentage base saturation is often higher in the deeper layers than in the surface of the profile samples. In the Litorina clays the variation between the different depths seems to be less regular. On the other hand, when some separate soil profiles are examined (Table 2), it is noticed that certain

Table 2. Data from various layers of different soil types

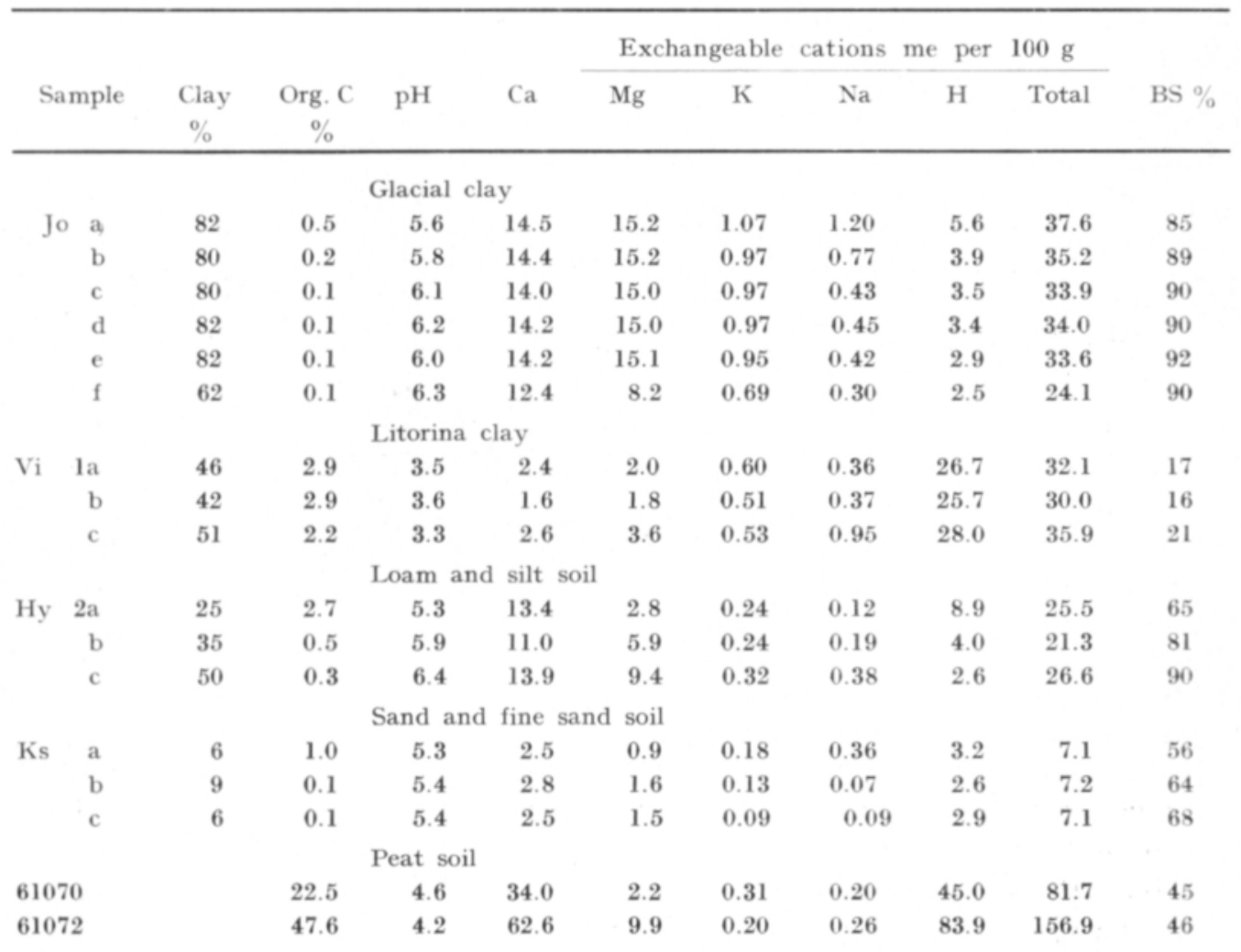


variation often appears in the deeper layers. In many cases finer fractions increase there, and while the soil type is changed, the exchange capacity and the percentage base saturation naturally vary, too.

As regards to individual cations, the exchangeable calcium and potassium appear to be highest in the surface layers of cultivated soils. The contents of these nutriens first decrease in the subsoil layers, but increase again in the ground layers. In the virgin soils the quantities of calcium and potassium generally tend to increase with the depth. Less magnesium appears to be found in the surface than in the deeper layers in all soil types. The amount of exchangeable sodium seems, on an average, slightly increase with the depth.

In this study the cultivated soils and virgin soils have not been grouped separately, but because their absolute amounts of exchangeable cations obviously differ from each other, the mean cation contents of the mineral soils were calculated for the both groups. The means with their confidence limits at 95 per cent level were the following:

\begin{tabular}{|c|c|c|c|}
\hline & Cultivated soils & $\begin{array}{l}\text { Virgin soils } \\
\text { ace layer }\end{array}$ & All mineral soils \\
\hline & $\mathrm{me} / 100 \mathrm{~g}$ & $\mathrm{me} / 100 \mathrm{~g}$ & $\mathrm{me} / 100 \mathrm{~g}$ \\
\hline $\mathrm{Ca}$ & $12.2 \pm 2.1$ & $4.6 \pm 1.8$ & $10.1 \pm 2.0$ \\
\hline $\mathbf{M g}$ & $1.0 \pm 0.7$ & $1.8 \pm 0.8$ & $1.9 \pm 0.6$ \\
\hline K & $0.49 \pm 0.14$ & $0.28 \pm 0.12$ & $0.43 \pm 0.10$ \\
\hline $\mathrm{Na}$ & $0.15 \pm 0.08$ & $0.35 \pm 0.34$ & $0.21 \pm 0.09$ \\
\hline $\mathbf{H}$ & $9.1 \pm 2.18$ & $\begin{array}{l}9.3 \pm 2.38 \\
\text { per layers }\end{array}$ & $9.2 \pm 1.9$ \\
\hline $\mathrm{Ca}$ & $9.0 \pm 2.0$ & $9.4 \pm 2.6$ & $9.2 \pm 1.5$ \\
\hline $\mathrm{Mg}$ & $5.5 \pm 1.5$ & $8.5 \pm 2.6$ & $6.7 \pm 1.4$ \\
\hline K & $0.44 \pm 0.10$ & $0.54 \pm 0.16$ & $0.48 \pm 0.10$ \\
\hline $\mathrm{Na}$ & $0.29 \pm 0.05$ & $0.42 \pm 0.14$ & $0.34 \pm 0.06$ \\
\hline H & $8.0 \pm 2.58$ & $5.9 \pm 3.55$ & $7.1 \pm 2.2$ \\
\hline
\end{tabular}

In comparing the means of the nutrient contents in the surface layers, where the effect of cultivation is mainly to be found, it is noticed that the amount of exchangeable calcium is appreciably higher in the cultivated than in the virgin soils. In this connection, however, attention must be paid to the fact that the group of virgin soils contained relatively less soils of finer texture than the group of cultivated soils. This fact, of course, has also an effect upon the difference between the cation contents of both the groups.

Potassium also occurs in a higher amount in the cultivated soils, the mean content of sodium, on the contrary, seems to be somewhat lower in the cultivated than in the virgin soils.

\section{Discussion}

The cation exchange capacity may range to a large degree, the variation being influenced by several factors. Among these are of importance e.g. the mineral composition of the soil, the climatic conditions, the adsorption properties of the soil colloids, the surface vegetation, and in the cultivated soils fertilization, liming, and the uptake of nutrients by the crops. 
Values of the characteristic exchange capacity for different soil types and their contents of exchangeable cations are given in many textbooks of soil science, e.g. for the American soils by Lyon et al. (11) and for the German soils by Scheffer and Schachtschabel (16). The means of the cation contents of some Swedish soils reported by WIKLANDER (20) may best represent the soils of our northern humid climate.

The CEC and BS values of the different soil types are of the same order as in the previous studies carried out in Finland. In the proper peat soils the range of exchange capacity is in good accordance with CEC values from 47 to 167 me per $100 \mathrm{~g}$ of soil reported by PUUSTJÄRvi (14) for samples of our peat soils. The CEC and BS values of the various clay soils also agree with results by KIVINEN (10), according to which BS \% ranged from 70 to 90 in 23 heavy clay soils, and in 18 Litorina clays the average BS \% was 21 . In the present work the highest CEC values are also obtained in the Glacial clay soils and the percentage base saturation ranges in them from 77 to 92 . The Litorina clays within this material have a little lower CEC values than the other clay samples but much lower percentages base saturation, $36 \%$ on the average.

When examining the individual cations the high content of magnesium is observable in all other clay soils except in the Litorina clays, a fact previously mentioned by Aarnio (2) and Heinonen (4). For the exchangeable cations of a so-called mideal" soil SchachтsснABEL (16) has proposed the following composition:

$\mathrm{H}: 0$ to $25 \%$, Ca: 60 to $85 \%, \mathrm{Mg}: 10$ to $15 \%, \mathrm{~K}: 3$ to $5 \%, \mathrm{Na}: 3 \%$. The cation exchange capacity of this wideal" soil varies from 10 to 25 me per $100 \mathrm{~g}$ of soil and its $\mathrm{pH}$ from 5.5 to 7.5. The optimum contents of this kind, however, cannot always be considered as generally accepted, as they greatly depend on the existing conditions e.g. on the composition of the soil (13) and on the plant concerned (12). The percentages of the exchangeable bases obtained within this material are, on the average, below the mideal" contents, hydrogen, on the contrary, appears to be present in a higher degree. The reason for this may be partly that this material contains besides samples of cultivated soils also samples of virgin soils, in which the base content often appears to be fairly low. On the other hand, in many individual samples the cation contents agree well with those of the optimum level.

Generally, the surface layer of the cultivated soils seems to contain the highest amounts of calcium and potassium as a result of fertilization and liming. The magnesium content seems to be highest in the deeper layers of the profiles in all soil types. A high magnesium content in the deeper layers of the soils has previously been found in the clay soils by AARnio (2) and in the peat soils by KAILA and KIVEKÄS (8). The distribution of this kind is to be expected, because it is known that magnesium is sorbed weakly by humic matter and very effectively by clay, and in many of the profiles the clay content tends to increase with depth.

\section{$S u m m a r y$}

An attempt was made to study the cation exchange capacity, the percentage base saturation and the amounts of the most common cations in the different types 
and depths of the Finnish soils on the basis of a material of 100 soil samples from various parts of the country.

The exchangeable cations were leached from the soil with neutral $1 \mathrm{~N}$ ammonium acetate. Calcium, magnesium, potassium, sodium and hydrogen were determined and the exchange capacity was calculated as the sum of all these cations.

In the different soil types the mean values of the $\mathrm{CEC}$ were the following:

$\begin{array}{lll}\text { organic soils } & 92.1 \text { me per } 100 \mathrm{~g} \text { of soil } \\ \text { non-Litorina clays } & 28.9 & 27.9 \\ \text { Litorina clays } & 16.9 & , \\ \text { loam and silt soils } & 14.5\end{array}$

The highest values of the percentage base saturation, on an average $85 \%$ were obtained in the Glacial clay soils and the lowest ones in the organic soils, $34 \%$, and in the Litorina clay soils, $36 \%$. BS \% was generally greater in the deeper than in the surface layers.

The contents of clay $(<2 \mu)$ and organic carbon explained 70 per cent of the variation in the exchange capacity of the mineral soils.

Among the exchangeable cations the magnesium content seemed to be relatively high especially in the clay soils, except in the Litorina clays. The contents of potassium and sodium seemed to be relatively rather low in the organic soils.

In the deeper layers exchangeable magnesium appeared to be higher than in the surface layers in all soil types. The amount of exchangeable sodium seemed also, on an average, slightly increase with the depth.

Generally, the results agreed well with the previous studies carried out in Finland.

\section{REFERENCES}

(1) Aarnio, B. 1938. Uber die Tone Finnlands und ihre Eigenschaften. Agrogeol. julk. 46: 1-27.

(2) $\rightarrow-1942$. Uber die Tone Finnlands und ihre Eigenschaften. II Die austauschbaren Basen. Ibid. 53: 1-24.

(3) Fieldes, M. \& King, P. J. T. et al. 1951. Estimation of exchangeable cations in soils with the Beckman flame spectrophotometer. Soil Sci 72: 219-232.

(4) Heinonen, R. 1956. Magnesiumin tarpeesta Suomen pelloissa. (Summary: Magnesium requirements in Finnish agriculture. Agrogeol. julk. 65: 1-31.

(5) - - 1960. Uber die Umtauschkapazität des Bodens und verschiedenen Bodenbestandteile in Finnland. Z. Pflanzenern. Düng. u. Bodenk. 88: 49-59.

(6) Henriksen, A. 1964. Om danske landbrugsjordens magnesiumtilstand og of grødernes magnesiumforsyning. Tidsk. Planteavl. 67: 733-783.

(7) JAскson, M. L. 1958. Soil chemical analyses XIV, 498 p. London.

(8) KaIla, A. \& KıveкÃs, J. 1956. Distribution of extractable calcium, magnesium, potassium and sodium in various depths of some virgin peat soils. J. Sci. Agric. Soc. Finland 28: 237-247.

(9) Keränen, T. 1946. Kaliumista Suomen malajeissa (Summary: On potassium in Finnish soils) Acta Agr. Fenn. 63: 113 p. Helsinki.

(10) Krvinen, E. 1937. Uber die austauschbaren Basen in Finnischen Tonböden. J. Sci Agric. Soc. Finland 9: 247-256. 
(11) Lyon, T. L. \& Buckman, H. O. \& Brady, N. C. 1952. The nature and properties of soils, 591 p. New York.

(12) Merlich, A. \& Drake, M. 1955. Soil chemistry and plant nutrition. Chemistry of soil $286-327$. New York.

(13) Mehlich, A. \& Reed, J. F. 1948. Effect of cation exchange properties of soil on the cation content plants. Soil Sci. 66: $289-306$.

(14) PuUstuärvi, V. 1956. On the cation exchange capacity of the peats and on the factors of influence upon its formation. Acta Agric. Scand. 6: 410-449.

(15) SAlonen, M. 1952. Vaihtuvien emästen ja vaihtuvan vedyn kokonaismäärien käytöstä maan kalkintarpeen arvioimisessa. (Summary: On the use of exchangeable hydrogen and the sum of exchangeable bases at determining the lime requirement of soil.) J. Sci. Agric. Soc. Finland 24: $135-136$.

(16) Scheffer, F. \& Sснаснтschabel, P. 1960. Bodenkunde I, 332 p. Stuttgart.

(17) Schollenberger, A. J. \& Simons, R. H. 1945. Determination of exchange capacity and exchangeable bases in soils. Soil Sci. 59: $13-24$.

(18) Soveri, U. \& HilPI, E. 1952. Saviemme raekoostumuksen määrittämisestä areometrillä (Abstract: The determination of the grain of clays by the areometric methods.) Techn. Review 10: $224-226$.

(19) WALKLeY, A. 1935. An examination of methods for determining organic carbon and nitrogen in soils. J. Agr. Sci. 25: 598-609.

(20) Wiklander, L. 1963. Den odlade markens kemiska egenskaper. Jord- Gröda- Jord 73-97. Stockholm.

S E L O S T U:

VAIHTUVISTA KATIONEISTA SUOMEN MAALAJEISSA

Ulla Martilla

Maanviljelyskemian laitos, Helsingin yliopisto.

Pihlajamäki

Tutkimuksessa on määritetty 1-n ammoniumasetaatilla vaihtuvat kalsiumin, magnesiumin, kaliumin, natriumin ja vedyn pitoisuudet sekä laskettu näiden kationien summana vaihtokapasiteettiarvot.

Tutkimusaineistona oli 100 maanäytettä maamme eri osista.

Eri maalajien kationinvaihtokapasiteetin keskiarvoiksi saatiin:

eloperäiset maat

ei-Litorinasavet

Litorinasavet

hiue- ja hiesumaat

hiekka- ja hietamaat

$92.1 \mathrm{me} / 100 \mathrm{~g}$
28.9
27.9
16.9
14.5

Emäskyllästysaste oli suurin glasiaalisavilla, keskimäärin $85 \%$, ja pienin eloperäisillä mailla, $34 \%$, ja Litorinasavilla $36 \%$. Emäskyllästysaste yleensä kasvoi syvempiin kerroksiin mentäessä.

Saveksen $(<2 \mu)$ ja orgaanisen hiilen pitoisuuden havaittiin selvittävän $70 \%$ vaihtokapasiteetin vaihteluista kivennäismailla.

Tarkasteltaessa erikseen yksityisten kationien määriä magnesiumin pitoisuus năytti olevan suhteellisen korkea erityisesti savimaissa paitsi Litorinasavissa. Kaliumia ja natriumia näytti esiintyvän suhteellisen vähän eloperäisissä maissa.

Vaihtuvan magnesiumin pitoisuus lisääntyi selvästi kaikkien maalajien syvemmissä kerroksissa. Vaihtuvan natriumin määrät näyttivät myös keskimäärin hiukan lisääntyvän syvyyden kasvaessa. 